\title{
In-vessel co-composting of yard waste and food waste: an approach for sustainable waste management in Cameron Highlands, Malaysia
}

\author{
Amirhossein Malakahmad $^{1}$ (D) Natasha Binti Idrus ${ }^{1} \cdot$ Motasem S. Abualqumboz $^{1}$. \\ Sara Yavari ${ }^{1}$ - Shamsul Rahman M. Kutty ${ }^{1}$
}

Received: 28 December 2016/Accepted: 19 April 2017/Published online: 25 April 2017

(c) The Author(s) 2017. This article is an open access publication

\begin{abstract}
Purpose Huge amount of yard waste is produced in cities with excessive agricultural activities like Cameron Highlands, Malaysia where most of the time the yard waste is being managed poorly and big portion of it ends in dump sites. Therefore, this study aims to evaluate the applicability of converting yard waste generated in Cameron Highlands Malaysia into high-quality and fast compost via in-vessel method.

Methods In-vessel composting technique was applied for speedy biotransformation of yard waste. Addition of food waste, effective microorganisms (EM) and Shimamoto Enzyme $^{\circledR}$ (SE) were investigated for improvement of compost quality. Four compositions of feedstock with different yard waste (YW) and food waste (FW) ratios were tested. The compositions were $70 \% \mathrm{YW}+30 \% \mathrm{FW}, \quad 80 \% \mathrm{YW}+$ $20 \% \mathrm{FW}, 90 \% \mathrm{YW}+10 \% \mathrm{FW}$ and $100 \% \mathrm{YW}$. Physicochemical properties of compost including $\mathrm{pH}$, moisture content and $\mathrm{C} / \mathrm{N}$ ratio were monitored throughout the experiment. Furthermore, quality of compost and its potential for direct application after production were evaluated based on germination index (GI) and nutrient content (NPK).

Results The compost samples had $\mathrm{pH}$ ranging from 7 to 9 and moisture content of $15.45-32.13 \%$. Initial $\mathrm{C} / \mathrm{N}$ ratio of all feedstock was decreased throughout the composting process by more than $50 \%$. Seed germination test showed that only $70 \% \mathrm{YW}+30 \% \mathrm{FW}$ feedstock produced immature compost with GI $<80 \%$. The highest GI of $130 \%$ was
\end{abstract}

Amirhossein Malakahmad

amirhossein@utp.edu.my; amalakahmad@gmail.com

1 Department of Civil and Environmental Engineering, Universiti Teknologi Petronas, 32610 Seri Iskandar, Perak Darul Ridzuan, Malaysia obtained when FW represented in $10 \%$ of the feedstock with addition of EM. Average concentrations of nitrogen, phosphorus and potassium were $1.73,1.21$ and $1.66 \%$ in case of EM additive and 1.47, 0.56 and $1.74 \%$ in case of SE additive.

Conclusion Application of in-vessel composting can improve solid waste management in Cameron Highlands, Malaysia and yield a high-demand product. The approach used in this study can be a good practice for the societies have difficulties in managing their yard waste.

Keywords Aerobic composting - Compost quality · Municipal solid waste $\cdot$ Effective microorganisms

\section{Introduction}

Landfilling has been the most adopted option for disposing of growing quantities of municipal solid waste (MSW) in Malaysia as it is the cheapest disposal option (Agamuthu 2013). Besides 114 non-operational landfills, the Malaysian ministry of Housing and Local Government is responsible for other 176 in-operation landfills (Fazeli et al. 2016). Out of the currently operating landfills, only 14 have been classified as sanitary landfills whereas the remaining are unsanitary (Noor et al. 2013). Many illegal dumpsites have been used in Malaysia for disposing of the waste (Malakahmad et al. 2013). Statistics show that more than $90 \%$ of collected comingled solid waste in Malaysia is disposed of in unsanitary landfills (Badgie et al. 2012; Johari et al. 2014). Nevertheless, organic fractions of MSW such as yard waste can be transformed into useful products through biological conversion technologies such as composting (Parthan et al. 2012; Rajaie and Tavakoly 2016). Yard waste and food waste collectively represented nearly $50 \%$ of waste stream in Malaysia (Dinie et al. 2013; 
Periathamby et al. 2009). However, composting of organic wastes has been practiced in Malaysia for only $1 \%$ of solid waste from 2000 to 2006 and it is projected to increase to $8 \%$ by 2020 (Johari et al. 2014). Mansor et al. (2015) stated that ample quantities of yard waste get generated in Malaysia from areas that have high agriculture activities such as Cameron Highlands. Cameron Highlands is the largest vegetable, flower and tea supplier in Malaysia (Aminu et al. 2015). While considerable portion of generated waste in Cameron Highlands is disposed of in unsanitary dumpsite near Tanah Rata, organic MSW including yard wastes can be converted into useful products via biological transformation methods.

Composting, as a biological waste transformation technique, can be defined as decomposition and stabilization of organic matters, commonly in the presence of oxygen, for production of stable and free-of-pathogen final product that can be beneficially applied to land (Haug 1993) for soil amendment (Ch'ng et al. 2013; Mhindu et al. 2013; Pandey et al. 2016). Generation of renewable energy (Irvine et al. 2010), saving lands by increasing lifetime of landfills (Hoornweg et al. 1999) and reduction of transportation costs (Larney et al. 2006; Mandal et al. 2014) are reported as other benefits of composting. Moreover, less amount of landfill gases (LFG) and leachate would be generated when organic materials are composted rather than landfilled (Lou and Nair 2009; Sudharsan Varma and Kalamdhad 2014).

Composting of organic MSW can be done using different methods such as windrow, aerated static pile, and in-vessel techniques. Selection of composting methods can be considered in respect to factors such as capital and operating costs, land availability, operational complexity and potential of nuisance problems. Although more expensive compared to other methods, in-vessel composing is more controlled, needs smaller spaces and resulted in less bothers than other techniques (Cekmecelioglu et al. 2005). In-vessel composting technique allows the highest degree of temperature control. In addition, it can be used to shorten the time needed for production of compost drastically (An et al. 2012). In Malaysia, in-vessel composting also has been successfully implemented for industrial wastes (Razali et al. 2012; Zahrim et al. 2016). Therefore, in this study composting of yard waste generated in Cameron Highlands was conducted using an in-vessel composter. Quality of compost was assessed via measurement of germination index and nutrient values.

\section{Methodology}

\section{Feedstock materials}

Yard waste (YW) was gathered from a plant nursery in Cameron Highlands, Malaysia. It was then shredded using mechanical shredder into smaller sizes with 4-5 cm maximum length. Shredding of organic waste into small sizes prior to composting results in faster stabilization (Tognetti et al. 2007). Food waste (FW) was collected from a nearby restaurant and comprised rice, chicken, potatoes, sausages, cooked spaghetti and green vegetables. The initial $\mathrm{pH}$ values of $\mathrm{YW}$ and $\mathrm{FW}$ were $6.17 \pm 0.2$ and $4.68 \pm 0.2$, respectively. Even though the optimum $\mathrm{pH}$ range for composting is 5.5-8, raw feedstock having a $\mathrm{pH}$ value within the range of 3-11 can also be composted (Pichtel 2005). YW used in this study had low initial moisture content of $35.63 \pm 0.4 \%$ while $\mathrm{FW}$ recorded moisture content of $58.24 \pm 0.4 \%$. Optimum initial moisture content of raw feedstock ranges between 50 and $60 \%$ (Kalamdhad and Kazmi 2009). The analyses showed that YW and FW contained $17.17 \pm 0.5 \%$ and $31.77 \pm 0.5 \%$ of carbon, and $0.28 \pm 0.2 \%$ and $3.43 \pm 0.2 \%$ of nitrogen. The $\mathrm{C} / \mathrm{N}$ ratios of $\mathrm{YW}$ and $\mathrm{FW}$ were $61.32 \pm 0.3$ and $9.26 \pm 0.2$, respectively. Initial carbon to nitrogen ratios between 25 and 50 are optimum for aerobic composting (Kumar et al. 2010; Zhu 2007). High C/N ratio causes slow growth of microorganisms and consequently organic decomposition will be slow (Maheshwari 2014). On the other hand, low $\mathrm{C} / \mathrm{N}$ ratio contributes to odor problems due to formation of ammonia or nitrous oxides. Blending of YW and FW can provide a near optimum $\mathrm{C} / \mathrm{N}$ ratio.

\section{In-vessel composter}

An in-vessel actual-size rotary drum composter (COMPOSTECH CT200) with the dimensions $l: 2.0 \times w$ : $1.1 \times h: 1.3 \mathrm{~m}^{3}$ was used in this study. Proper rotation in these kinds of composting machines is an efficient technique which produces uniform end product due to good agitation, aeration and mixing of the compost (Rich and Bharti 2015). The composter was able to handle $200 \mathrm{~kg}$ of waste at maximum. It was equipped with three rotary blades for mixing of materials and an air blower to maintain enough oxygen levels inside the chamber. Away from ambient temperatures which were 30 and $23{ }^{\circ} \mathrm{C}$ on average for day time and night time, respectively, the temperature inside the composter was automatically controlled at $56 \pm 4{ }^{\circ} \mathrm{C}$ using heating functions and sensors equipped in the composter. The temperature inside the composter changed mainly due to heat generation as a result of degradation of organic matters by microorganisms and because of ambient air blown inside the composter for aeration purposes (Arslan Topal et al. 2016). Greatest thermophilic activity would be observed during composting process when the temperature ranges between 52 and $60{ }^{\circ} \mathrm{C}$ (Kalamdhad and Kazmi 2009; Mohee and Mudhoo 2005). 
Table 1 Combinations of yard waste (YW), food waste (FW) and additives in samples

\begin{tabular}{|c|c|c|c|}
\hline \multirow[t]{2}{*}{ Compost proportion } & \multicolumn{3}{|c|}{ Weight of material $(\mathrm{kg})$} \\
\hline & YW & FW & Additives \\
\hline \multicolumn{4}{|c|}{ Effective microorganisms (EM) } \\
\hline $100 \% \mathrm{YW}$ & 12.0 & 0 & 8.0 \\
\hline $90 \% \mathrm{YW}+10 \% \mathrm{FW}$ & 10.8 & 1.2 & 8.0 \\
\hline $80 \% \mathrm{YW}+20 \% \mathrm{FW}$ & 9.6 & 2.4 & 8.0 \\
\hline $70 \% \mathrm{YW}+30 \% \mathrm{FW}$ & 8.4 & 3.6 & 8.0 \\
\hline \multicolumn{4}{|c|}{ Shimamoto Enzyme ${ }^{\circledR}$ (SE) } \\
\hline $100 \% \mathrm{YW}$ & 20.0 & 0 & 1.0 \\
\hline $90 \% \mathrm{YW}+10 \% \mathrm{FW}$ & 18.0 & 2.0 & 1.0 \\
\hline $80 \% \mathrm{YW}+20 \% \mathrm{FW}$ & 16.0 & 4.0 & 1.0 \\
\hline $70 \% \mathrm{YW}+30 \% \mathrm{FW}$ & 14.0 & 6.0 & 1.0 \\
\hline
\end{tabular}

\section{Composting process}

Four different compositions of feedstock with different YW + FW mixtures were examined (Table 1). Addition of food waste was driven by the fact that at specific $\mathrm{C} / \mathrm{N}$ ratios for initiating composting, digester operating characteristics and end performance metrics can be improved (Brown and $\mathrm{Li}$ 2013). The compositions were (1) $100 \% \mathrm{YW}$, (2) $90 \% \mathrm{YW}+10 \% \mathrm{FW}$, (3) $80 \% \mathrm{YW}+20 \% \mathrm{FW}$, and (4) $70 \% \mathrm{YW}+30 \% \mathrm{FW}$. Each composition was composted twice using different additives. $8.0 \mathrm{~kg}$ of Effective Microorganisms (EM) and $1.0 \mathrm{~kg}$ of Shimamoto Enzyme ${ }^{\circledR}$ (SE) were used in each trial. EM and SE were added to the compost in values recommended by their manufacturing companies to improve and facilitate composting process. Compost additives increase the macro- and micronutrient content and result in more nitrogen $(\mathrm{N})$, phosphorus $(\mathrm{P})$ and potassium (K) nutrient content (NPK) (Jusoh et al. 2013). All prepared feedstock were composted in batches inside the composter for $24 \mathrm{~h}$. Subsequently, approximately $7 \mathrm{~kg}$ of the product of each batch was unloaded from the composter and processed further for curing purposes. The curing process lasted for 35 days. The remaining amounts of the product (approximately $13 \mathrm{~kg}$ ) were left inside the composter and recycled in the next batch.

\section{Compost quality control}

Existence of toxic substances is one of the common problems in immature composts (Itävaara et al. 2002). Therefore, phytotoxicity test is an important investigation to check the quality of compost before its application in different crops. In this study, compost extract was prepared initially with $200 \mathrm{~mL}$ of distilled water and $20 \mathrm{~g}$ of compost. The compost-water mixture was then stirred for $6 \mathrm{~h}$ and centrifuged at $8000 \mathrm{rpm}$ for $20 \mathrm{~min}$ (Gariglio et al.
2002; Mitelut and Popa 2011). Seed germination was tested for 20 radish seeds in Petri dishes (El Fels et al. 2014). Seeds were soaked with $5 \mathrm{~mL}$ of compost extract and left for 5 days in darkness at $22 \pm 3{ }^{\circ} \mathrm{C}$. Then, they were preserved in distilled water overnight before germination test. A blank sample filled with distilled water was used as control. At the end of the experiment, the germination index (GI) was obtained based on the following equations explained by Zucconi et al. (1981).

$$
\begin{aligned}
& \text { Relative seed germination }(\%) \\
& =\frac{\text { No. of seeds germinated in compost extract }}{\text { No. of seeds germinates in control }} \times 100 \% \text {, }
\end{aligned}
$$

Relative root growth (\%)

$$
=\frac{\text { Mean root length in compost extract }(\mathrm{mm})}{\text { Mean root length in control }(\mathrm{mm})} \times 100 \% \text {, }
$$

Germination index GI (\%)

$$
=\frac{\text { Relative seed germination } \times \text { relative root growth }}{100} \text {. }
$$

Besides the seed germination test, the NPK content of produced compost was also determined. Total Kjeldahl nitrogen (TKN) test was used for nitrogen content determination using BUCHI Distillation Unit K-314. As for phosphorus and potassium content, collected samples were first digested using dry digestion method. Then, $1 \mathrm{~g}$ of dry solid sample was placed in a $10-\mathrm{mL}$ crucible and heated at $550{ }^{\circ} \mathrm{C}$ in a muffle furnace for $5 \mathrm{~h}$. Afterwards, total phosphorus and total potassium were determined using PhosVer ${ }^{\circledR} 3$ ascorbic acid and atomic absorption spectroscopy (AAS), respectively, and the results were compared with available standards. In addition, and for benchmarking purpose, quality of samples was compared with a compost produced in windrow system using similar yard waste applied in this study. Nitrogen, phosphorous and potassium content of the compost produced in windrow system were $0.77 \pm 0.2, \quad 0.92 \pm 0.1$ and $1.58 \pm 0.1$, respectively.

\section{Results and discussion}

\section{Composting process}

Figure 1 shows initial $\mathrm{pH}$ of $\mathrm{FW}$ and YW feedstock and final $\mathrm{pH}$ of four matured compost compositions. $\mathrm{pH}$ varied from 7.01 to 9.17 in investigated compositions. Mature compost usually has a pH range of 6-8 (Cooperband 2002). In compost samples with EM additives, $\mathrm{pH}$ values 
Fig. $1 \mathrm{pH}$ levels of FW and YW feedstock and matured compost samples collected after curing with application of EM and SE additives

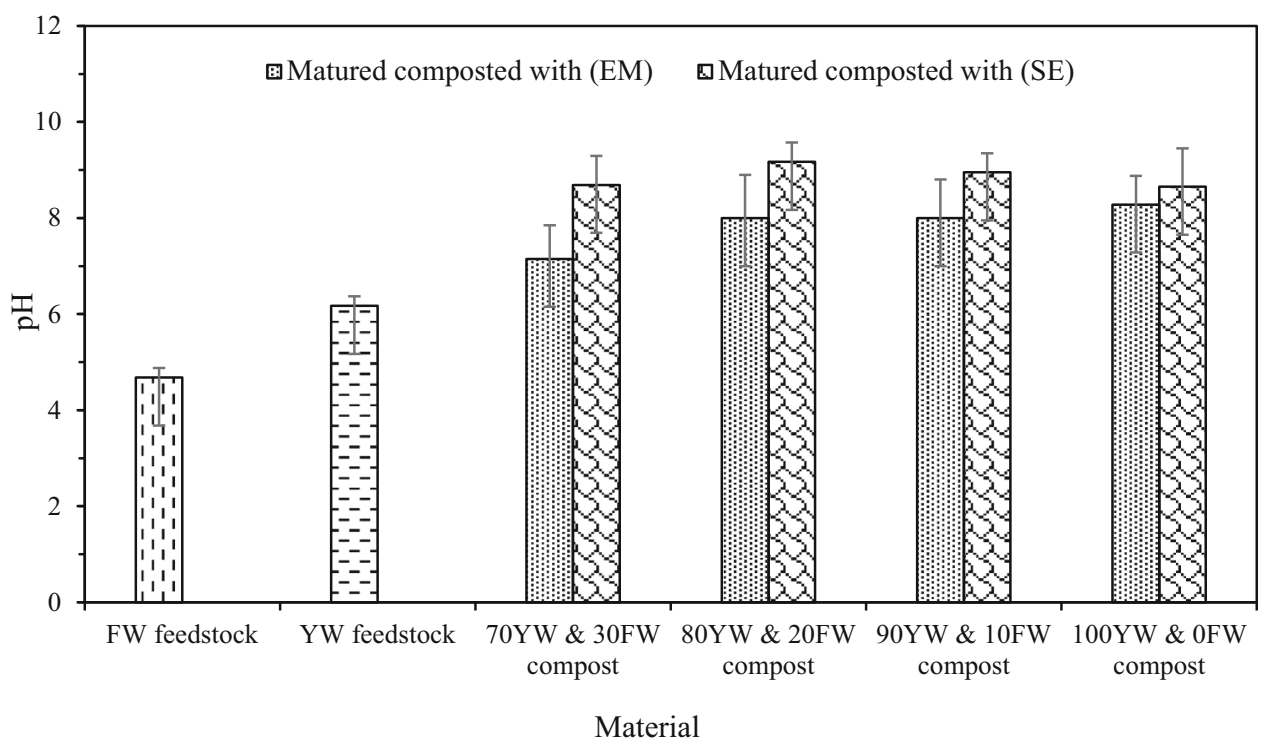

decreased and reached an optimum range. However, samples with $\mathrm{SE}$ additives had $\mathrm{pH}$ higher than optimum range. Effective microorganisms produce organic acids and cause reduction of $\mathrm{pH}$ (El-Shafei et al. 2008). High $\mathrm{pH}$ values of compost with SE additive could be due to consumption of produced organic acids at the beginning of the process and their conversion to ammonia (Sundberg 2005). Reduction of final $\mathrm{pH}$ value of compost can be achieved using different ways, e.g., addition of elemental sulfur (Roig et al. 2004). It was also found that addition of FW could slightly reduce $\mathrm{pH}$ of samples. Effect of food waste in lowering $\mathrm{pH}$ values was also confirmed by Saad et al. (2013).

Figure 2 shows moisture content values of raw FW and YW feedstock and of composts produced from different compositions of YW and FW. Samples recorded moisture contents ranging from 15.4 to $32.1 \%$ which were lower than the optimum levels. Moisture content should be in the range between 50 and $60 \%$ during the composting process (Tchobanoglous et al. 1993). Low initial moisture content of $\mathrm{YW}$ is believed to be the reason for having low final moisture content in compost samples. Application of yard waste for reducing compost pile moisture due to its high consumption of moisture content has been reported (Rihani et al. 2010). In addition, water contained in the feedstock is consumed during decomposition of organics and consequently the moisture content decreases over time. Therefore, adding enough water into the feedstock prior to composting to maintain an acceptable percentage of moisture content could improve the final moisture content of the compost samples.

$\mathrm{C} / \mathrm{N}$ ratio of compost ranged from 20 to 27 after 1 day of feedstock processing inside the composter (Fig. 3). Obtained $\mathrm{C} / \mathrm{N}$ ratios indicated that composting process succeeded in decreasing initial $\mathrm{C} / \mathrm{N}$ ratio of the feedstock in large percentage. For instance, initial $\mathrm{C} / \mathrm{N}$ ratio of the $100 \%$ YW feedstock was reduced around 56 and $65 \%$, respectively, in case of EM and SE additives' application. Similar reduction percentages in initial $\mathrm{C} / \mathrm{N}$ ratio were reported by other researchers (Jusoh et al. 2013; Makan and Mountadar 2012; Tumuhairwe et al. 2009). Organic carbon gets converted to $\mathrm{CO}_{2}$ during composting process and, with minimal nitrogen loss the $\mathrm{C} / \mathrm{N}$ ratio of compost will eventually decrease (Rasapoor et al. 2016). C/N ratio of finished compost is desired to be close to 10/1. Curing process can reduce further the $\mathrm{C} / \mathrm{N}$ ratio of compost and resulted in a proper ratio (Shaffer 2010).

\section{Compost quality}

Figure 4 shows germinated radish seeds in control and in sample of composts with EM and SE additives. Results of seed germination test are shown in Fig. 5. All samples, except sample of $70 \% \mathrm{YW}+30 \% \mathrm{FW}$ with EM additive, could produce satisfactory germination indexes.

Minimum acceptable germination index (GI) of mature compost for different seeds types have been investigated previously. Riffaldi et al. (1986) studied GI of garden cress and reported that compost is certainly not phytotoxic to plants when GI is more than $80 \%$. Similar to garden cress seeds, germination indexes of at least $80 \%$ in radish seeds (Mitelut and Popa 2011) and cucumber seeds (Sangamithirai et al. 2015) indicated production of compost which is not phytotoxic. Investigated compost samples in this study recorded germination index higher than those achieved by Kumar et al. (2010) during co-composting of green waste and food waste at low $\mathrm{C} / \mathrm{N}$ ratio using an invessel lab-scale reactor. Generally, the phytotoxicity effect is most likely due to the presence of fatty substance, 

and YW feedstock and matured compost samples collected after curing with application of EM and SE additives
Fig. 2 Moisture content of FW

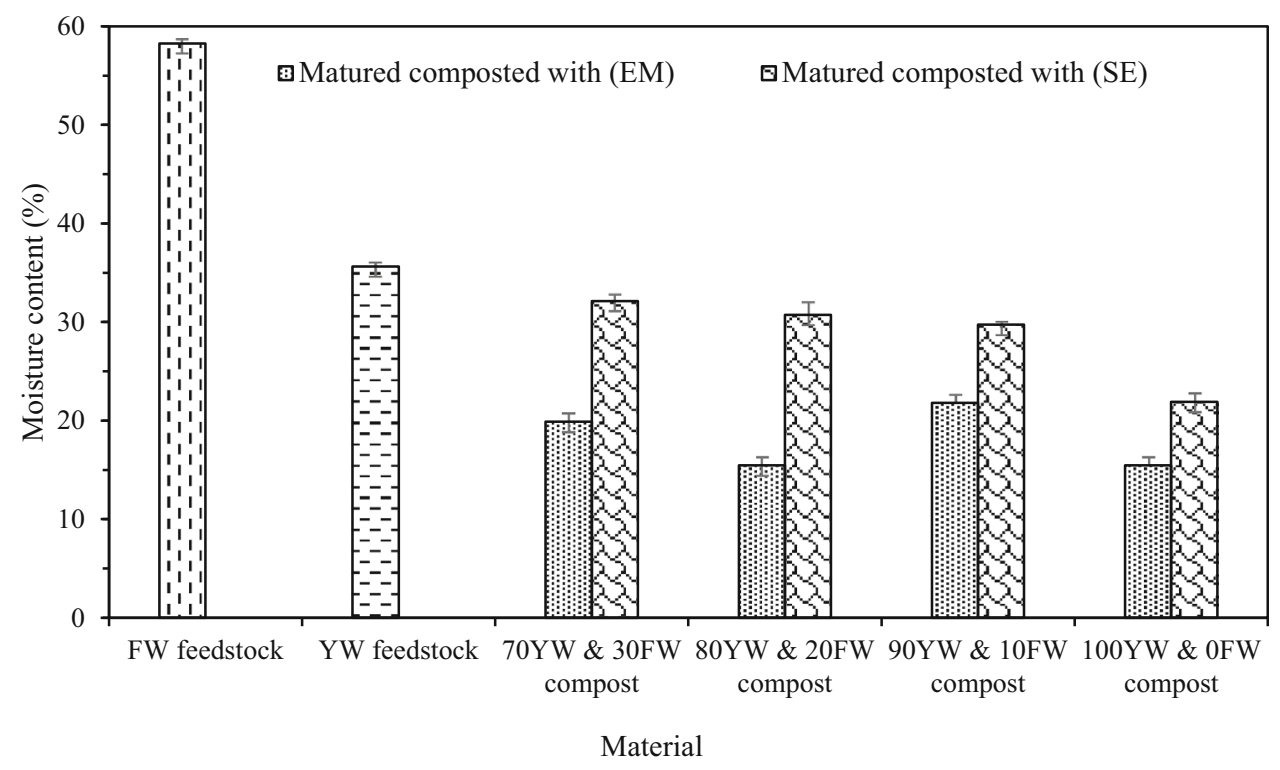

Fig. $3 \mathrm{C} / \mathrm{N}$ ratio of $\mathrm{FW}$ and YW feedstock and matured compost samples collected after curing with application of EM and SE additives

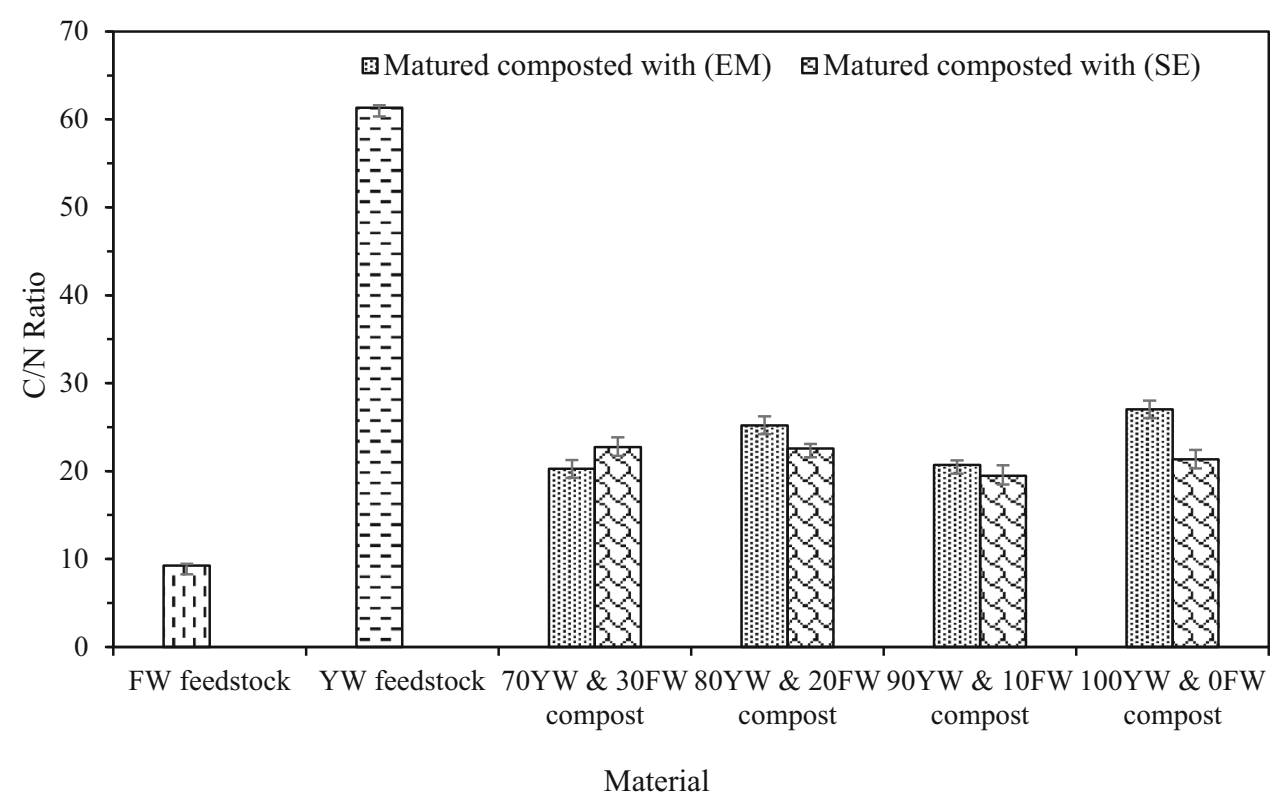

compost quality, should be sufficient for plant growth (Rihani et al. 2010). All feedstock produced composts with acceptable levels of NPK. Good quality compost should have $0.4-3.5 \%$ nitrogen, $0.3-3.5 \%$ phosphorus and 0.5-1.8\% potassium (Jaafarzadeh Haghighi Fard et al. 2015; Sadeghi et al. 2015). Addition of EM resulted in production of compost with higher percentages of nitrogen and phosphorus compared to SE. With addition of EM, feedstock with $10 \%$ FW recorded the best NPK value. Percentages of phosphorus and potassium decreased as FW percentage in the feedstock increased. In composts with SE additive, supplement of FW has no effect on phosphorus and potassium contents and almost similar percentages of $\mathrm{P}$ 2011). Hence, NPK content of compost, as a benchmark for 
Fig. 4 Seed germination test of control and compost produced using the $100 \% \mathrm{YW}$,

$90 \% \mathrm{YW}+10 \% \mathrm{FW}$,

$80 \% \mathrm{YW}+20 \% \mathrm{FW}$ and

$70 \%$ YW $+30 \%$ FW feedstock

in case of EM (a-d) and SE (e-

h) additives

\section{Control}

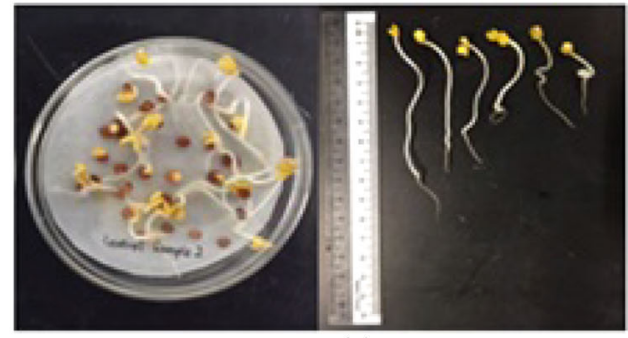

(e)

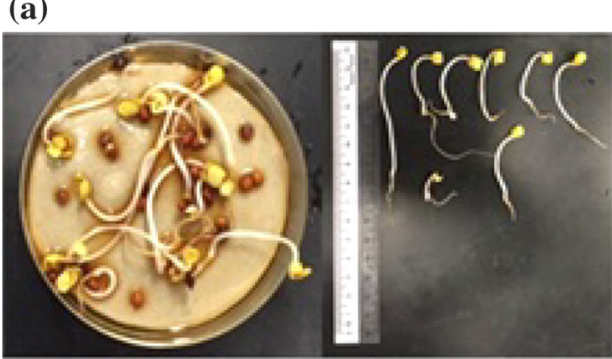

(b)

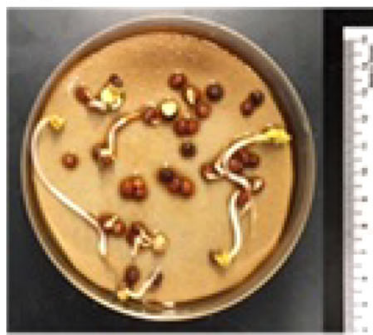

(c)

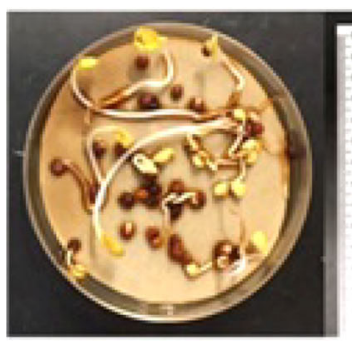

(d)

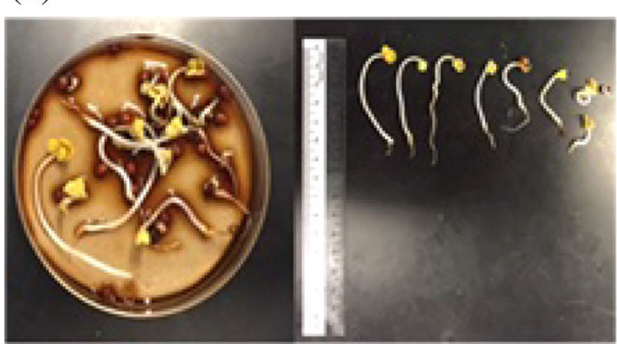

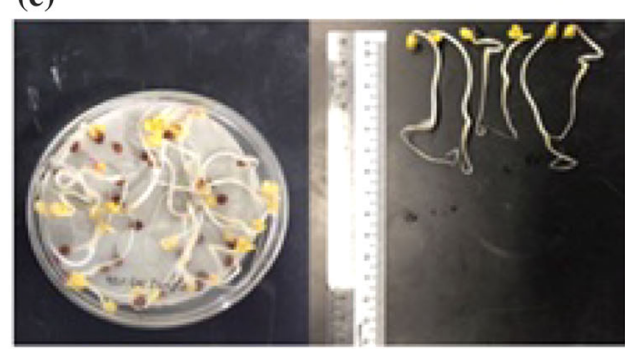

(f)

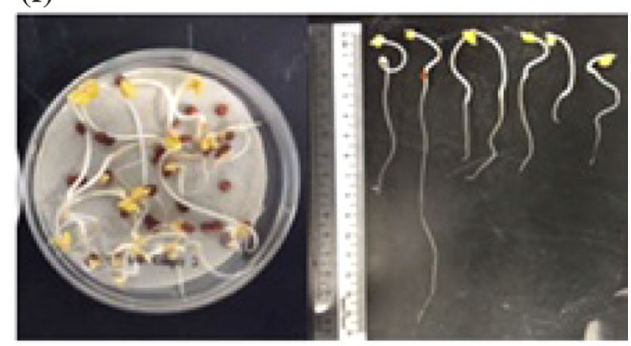

(g)

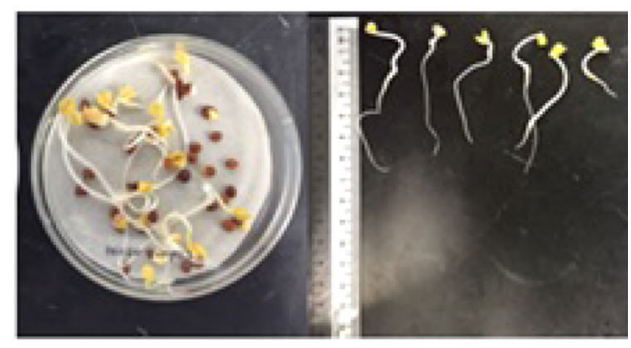

(h)

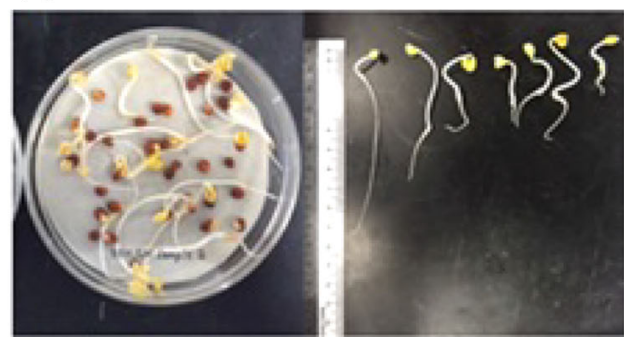

and $\mathrm{K}$ were recorded in all compost samples. Nitrogen content, however, varied based on FW percentages. When compared with the compost produced using windrow method, with NPK values of $0.77 \% \pm 0.2,0.92 \% \pm 0.1$ and $1.58 \% \pm 0.1$, composts produced in this study had better NPK content.

\section{Conclusion}

In-vessel co-composting of yard waste and food waste generated in Cameron Highlands, Malaysia was investigated with addition of effective microorganisms (EM) and Shimamoto Enzyme ${ }^{\circledR}(\mathrm{SE})$ in an actual-size composter. 


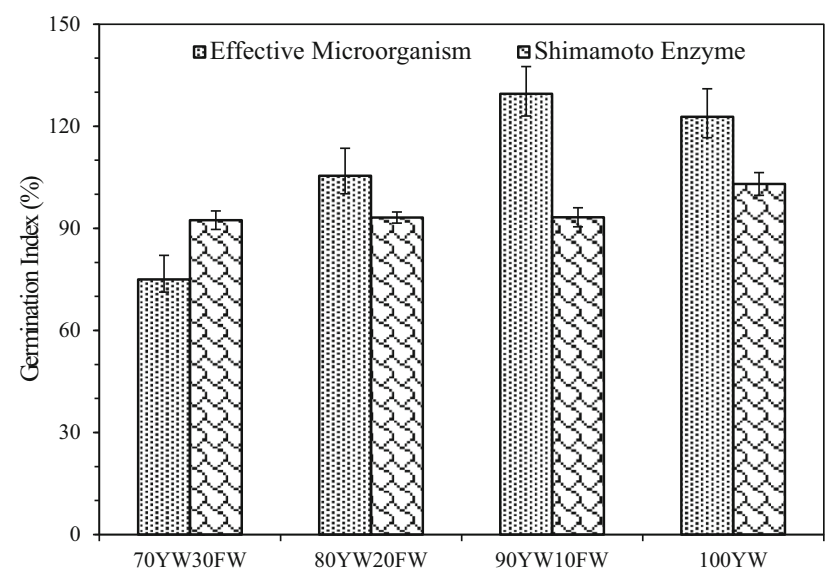

Fig. 5 Germination index results of produced compost with application of EM and SE additives
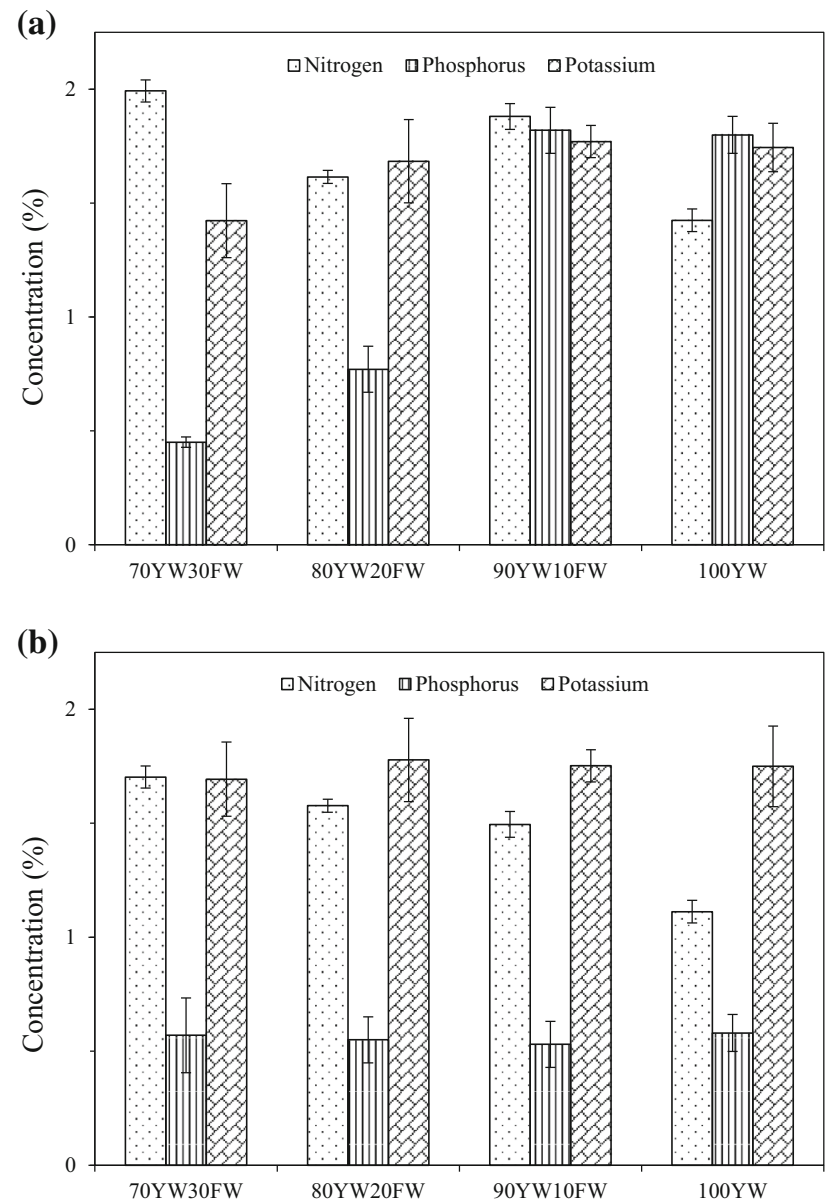

Fig. 6 NPK content of different compost compositions in case of a EM and $\mathbf{b}$ SE additives

Acceptable reduction of $\mathrm{pH}$ and $\mathrm{C} / \mathrm{N}$ ratio was observed, specifically with the addition of effective microorganisms to the feedstock. All samples had insufficient moisture contents due to high percentage of yard waste in feedstock. Maturity tests of germination index and NPK value indicated better quality of compost with EM additives compared to those with SE additive. Composts produced in this study have shown superior quality compared to the one produced in windrow method. Biological transformation of yard waste instead of its landfilling is not only a promising solution to overcome growing problems of solid waste management, but also reduces air and water pollution. Invessel composting of yard waste instead of its windrow or aerated pile composting in Cameron Highlands, where the lands are in great demand, is an environmentally friendly and sustainable approach for solid waste management.

Acknowledgements This study was supported by the Ministry of Higher Education, Malaysia (MOHE) under classification of MyRA Grant scheme (0153AB-J13). Authors are thankful to Mr. Zaaba Mohammad and Mr. Ali Boualili for their kind assistance in this research. Cooperation from Mr. Leong Hua Qian and Magnificent Associated Nurseries Sdn Bhd for providing yard waste is highly appreciated.

Open Access This article is distributed under the terms of the Creative Commons Attribution 4.0 International License (http://crea tivecommons.org/licenses/by/4.0/), which permits unrestricted use, distribution, and reproduction in any medium, provided you give appropriate credit to the original author(s) and the source, provide a link to the Creative Commons license, and indicate if changes were made.

\section{References}

Agamuthu P (2013) Landfilling in developing countries. Waste Manag Res 31:1-2. doi:10.1177/0734242X12469169

Aminu M, Matori AN, Yusof KW, Malakahmad A, Zainol RB (2015) A GIS-based water quality model for sustainable tourism planning of Bertam River in Cameron Highlands, Malaysia. Environ Earth Sci 73:6525-6537. doi:10.1007/s12665-0143873-6

An C-J, Huang G-H, Yao Y, Sun W, An K (2012) Performance of invessel composting of food waste in the presence of coal ash and uric acid. J Hazard Mater 203-204:38-45. doi:10.1016/j. jhazmat.2011.11.066

Arslan Topal EI, Ünlü A, Topal M (2016) Effect of aeration rate on elimination of coliforms during composting of vegetable-fruit wastes. Int J Recycl Org Waste Agric 5:243-249. doi:10.1007/ s40093-016-0134-6

Badgie D, Samah M, Manaf LA, Muda AB (2012) Assessment of municipal solid waste composition in Malaysia: management, practice and challenges. Pol J Environ Stud 21:539-547. http:// www.nswaienvis.nic.in/Waste_Portal/Research_papers/pdf/Assess ment_of_MWS_Composition.pdf

Bojović B, Marković A (2009) Correlation between nitrogen and chlorophyll content in wheat (Triticum aestivum L.). Kragujevac J Sci 31:69-74. http://www.pmf.kg.ac.rs/KJS/volumes/kjs31/ kjs31bojovicmarkovic69.pdf

Brown D, Li Y (2013) Solid state anaerobic co-digestion of yard waste and food waste for biogas production. Bioresour Technol 127:275-280. doi:10.1016/j.biortech.2012.09.081

Cekmecelioglu D, Demirci A, Graves RE, Davitt NH (2005) Applicability of optimised in-vessel food waste composting for windrow systems. Biosyst Eng 91:479-486. doi:10.1016/j. biosystemseng.2005.04.013 
Ch'ng HY, Ahmed OH, Kassim S, Majid NMA (2013) Co-composting of pineapple leaves and chicken manure slurry. Int J Recycl Org Waste Agric 2:23. doi:10.1186/2251-7715-2-23

Cooperband L (2002) The art and science of composting, a resource for farmers and compost producers. Center for Integrated agricultural systems, University of Wisconsin-Madison, Wisconsin, USA. http://www.cias.wisc.edu/wp-content/uploads/ 2008/07/artofcompost.pdf

Dinie M, Samsudin M, Don M (2013) Municipal solid waste management in malaysia: current practices, challenges and prospects. J Teknol 62:95-101. doi:10.11113/jt.v62.1293

El Fels L, Zamama M, El Asli A, Hafidi M (2014) Assessment of biotransformation of organic matter during co-composting of sewage sludge-lignocellulosic waste by chemical, FTIR analyses, and phytotoxicity tests. Int Biodeter Biodegr 87:128-137. doi:10.1016/j.ibiod.2013.09.024

El-Shafei A, Yehia M, El-Naqib F (2008) Impact of effective microorganisms compost on soil fertility and rice productivity and quality. Misr J Ag Eng 25:1067-1093. http://www.mjae.eg. net/pdf/2008/july/26.pdf

Fazeli A, Bakhtvar F, Jahanshaloo L, Che Sidik NA, Bayat AE (2016) Malaysia's stand on municipal solid waste conversion to energy: a review. Renew Sust Energ Rev 58:1007-1016. doi:10.1016/j. rser.2015.12.270

Gariglio NF, Buyatti MA, Pilatti RA, Russia DEG, Acosta MR (2002) Use of a germination bioassay to test compost maturity of willow (Salix sp.) sawdust. New Zeal J Crop Hort 30:135-139. doi:10. 1080/01140671.2002.9514208

Gastal F, Lemaire G (2002) N uptake and distribution in crops: an agronomical and ecophysiological perspective. J Exp Bot 53:789-799. https://www.ncbi.nlm.nih.gov/pubmed/11912222

Haug RT (1993). The practical handbook of compost engineering. CRC Press, Taylor \& Francis Group, USA. https://www. crcpress.com/The-Practical-Handbook-of-Compost-Engineering/ Haug/p/book/9780873713733

Hoornweg D, Thomas L, Otten L (1999). Composting and its applicability in developing countries. Working paper series No. 8. Urban Development Division, The World Bank, Washington DC, USA. http://www.bvsde.paho.org/bvsacd/cd48/paperseries8. pdf

Irvine G, Lamont E, Antizar-Ladislao B (2010) Energy from waste: reuse of compost heat as a source of renewable energy. Int $\mathrm{J}$ Chem Eng 2010:1-10. doi:10.1155/2010/627930

Itävaara M, Venelampi O, Vikman M, Kapanen A (2002) Compost maturity-problems associated with testing. Microbiology of composting 373-382. Springer, Berlin. doi:10.1007/978-3-66208724-4_31

Jaafarzadeh Haghighi Fard N, Moradi B, Abbasi M, Alivar Babadi R, Bahrani H, Mirzaie A, Zare Javid A, Ravanbakhsh M (2015) Feasibility study of green wastes composting with digested and dewatering sludge from municipal wastewater treatment plant in Iran. Environ Health Eng Manag J 2:149-155. http://ehemj.com/ browse.php?a_id=95\&sid=1\&slc_lang=en

Johari A, Alkali H, Hashim H, Ahmed SI, Mat R (2014) Municipal solid waste management and potential revenue from recycling in Malaysia. Mod Appl Sci 8:37-49. doi:10.5539/mas.v8n4p37

Jusoh MLC, Manaf LA, Latiff PA (2013) Composting of rice straw with effective microorganisms (EM) and its influence on compost quality. Iran J Environ Health Sci Eng 10:1-9. doi:10. 1186/1735-2746-10-17

Kalamdhad AS, Kazmi AA (2009) Rotary drum composting of different organic waste mixtures. Waste Manag Res 27:129-137. doi:10.1177/0734242X08091865

Kumar M, Ou Y-L, Lin J-G (2010) Co-composting of green waste and food waste at low $\mathrm{C} / \mathrm{N}$ ratio. Waste Manag 30:602-609. doi:10. 1016/j.wasman.2009.11.023
Larney FJ, Sullivan DM, Buckley KE, Eghball B (2006) The role of composting in recycling manure nutrients. Can J Soil Sci 86:597-611. doi:10.4141/S05-116

Lou XF, Nair J (2009) The impact of landfilling and composting on greenhouse gas emissions-a review. Bioresour Technol 100:3792-3798. doi:10.1016/j.biortech.2008.12.006

Maathuis FJ (2009) Physiological functions of mineral macronutrients. Curr Opin Plant Biol 12:250-258. doi:10.1016/j.pbi.2009. 04.003

Maheshwari DK (2014) Composting for sustainable agriculture. Springer International Publishing, Switzerland. doi:10.1007/9783-319-08004-8

Makan A, Mountadar M (2012) Effect of C/N ratio on the in-vessel composting under air pressure of organic fraction of municipal solid waste in Morocco. J Mater Cycles Waste Manag 14:241-249. doi:10.1007/s10163-012-0062-0

Malakahmad A, Nasrudin S, Basri NEA, Zain SM (2013) Anaerobic transformation of biodegradable waste; simultaneous production of energy and fertilizer. Am J Environ Sci 9:113-119. doi:10. 3844/ajessp.2013.113.119

Malvi UR (2011) Interaction of micronutrients with major nutrients with special reference to potassium. Karnataka J Agric Sci 24:106-109. http://www.inflibnet.ac.in/ojs/index.php/KJAS/arti cle/viewFile/865/795

Mandal P, Chaturvedi MK, Bassin JK, Vaidya AN, Gupta RK (2014) Qualitative assessment of municipal solid waste compost by indexing method. Int J Recycl Org WasteAgric 3:133-139. doi:10.1007/s40093-014-0075-x

Mansor N, Mat Rashid K, Mohamad Z, Abdullah Z (2015) Agro tourism potential in Malaysia. Int Acad Res $\mathrm{J}$ Bus Technol 1:37-44. http://www.iarjournal.com/wp-content/uploads/ IBTC2015-p37-44.pdf

Mhindu RL, Wuta M, Ngorima E (2013) Composting of selected organic wastes from Peri-urban areas of Harare, Zimbabwe. Int J Recycl Org Waste Agric 2:14. doi:10.1186/2251-7715-2-14

Mitelut AC, Popa ME (2011) Seed germination bioassay for toxicity evaluation of different composting biodegradable materials. Rom Biotechnol Lett 16:121-129. http://www.rombio.eu/ rbl1vol16Supplement/18\%20Amalia\%20Mitelut.pdf

Mohee R, Mudhoo A (2005) Analysis of the physical properties of an in-vessel composting matrix. Powder Technol 155:92-99. doi:10.1016/j.powtec.2005.05.051

Noor ZZ, Yusuf RO, Abba AH, Abu Hassan MA, Mohd Din MF (2013) An overview for energy recovery from municipal solid wastes (MSW) in Malaysia scenario. Renew Sustain Energy Rev 20:378-384. doi:10.1016/j.rser.2012.11.050

Pandey PK, Vaddella V, Cao W, Biswas S, Chiu C, Hunter S (2016) In-vessel composting system for converting food and green wastes into pathogen free soil amendment for sustainable agriculture. J Clean Prod 139:407-415. doi:10.1016/j.jclepro. 2016.08.034

Parthan SR, Milke MW, Wilson DC, Cocks JH (2012) Cost estimation for solid waste management in industrialising regions-precedents, problems and prospects. Waste Manag 32:584-594. doi:10.1016/j.wasman.2011.11.004

Periathamby A, Hamid FS, Khidzir K (2009) Evolution of solid waste management in Malaysia: impacts and implications of the solid waste bill, 2007. J Mater Cycles Waste Manag 11:96-103. doi:10.1007/s10163-008-0231-3

Pichtel J (2005) Waste management practices: municipal, hazardous, and industrial. CRC Press, Taylor \& Francis Group, Boca Raton. https://www.crcpress.com/Waste-Management-Practices-Munici pal-Hazardous-and-Industrial-Second/Pichtel/p/book/9781466585 188

Piotrowska-Cyplik A et al (2013) Composting of oiled bleaching earth: fatty acids degradation, phytotoxicity and mutagenicity 
changes. Int Biodeterior Biodegrad 78:49-57. doi:10.1016/j. ibiod.2012.12.007

Rajaie M, Tavakoly AR (2016) Effects of municipal waste compost and nitrogen fertilizer on growth and mineral composition of tomato. Int J Recycl Org Waste Agric 5:339-347. doi:10.1007/ s40093-016-0144-4

Rasapoor M, Adl M, Pourazizi B (2016) Comparative evaluation of aeration methods for municipal solid waste composting from the perspective of resource management: a practical case study in Tehran, Iran. J Environ Manag 184:528-534. doi:10.1016/j. jenvman.2016.10.029

Razali WAW, Baharuddin AS, Talib AT, Sulaiman A, Naim MN, Hassan MA, Shirai Y (2012) Degradation of oil palm empty fruit bunches (OPEFB) fibre during composting process using invessel composter. BioResources 7:4786-4805. doi:10.1007/ s40093-016-0131-9

Rich N, Bharti A (2015) Assessment of different types of in-vessel composters and its effect on stabilization of MSW compost. Int Res J Eng Technol 2:37-42. https://www.irjet.net/archives/V2/ i3/Irjet-v2i308.pdf

Riffaldi R, Levi-Minzi R, Pera A, De Bertoidi M (1986) Evaluation of compost maturity by means of chemical and microbial analyses. Waste Manag Res 4:387-396. doi:10.1177/0734242X86 00400157

Rihani M, Malamis D, Bihaoui B, Etahiri S, Loizidou M, Assobhei O (2010) In-vessel treatment of urban primary sludge by aerobic composting. Bioresour Technol 101:5988-5995. doi:10.1016/j. biortech.2010.03.007

Roig A, Cayuela ML, Sánchez-Monedero MA (2004) The use of elemental sulphur as organic alternative to control $\mathrm{pH}$ during composting of olive mill wastes. Chemosphere 57:1099-1105. doi:10.1016/j.chemosphere.2004.08.024

Ristvey AG, Lea-Cox JD, Ross, DS (2007) Nitrogen and phosphorus uptake efficiency and partitioning of container-grown azalea during spring growth. J Am Soc Hortic Sci 132:563-571. http:// journal.ashspublications.org/content/132/4/563.full

Saad M, Fatin N, Nadrah Ma'min N, Zain SM, Basri NEA, Zaini M, Sofia N (2013) Composting of mixed yard and food wastes with effective microbes. J Teknol 65:89-95. doi:10.11113/jt.v65.2196
Sadeghi S, Dehvari M, Bahmani P, Teymouri P, Fattahi A, Sadeghnia M, Fallahzadeh RA (2015) Physical-chemical analysis and comparison with standards of the compost produced in Sanandaj, Iran. Open Access Libr J 2:1-6. doi:10.4236/oalib.1101855

Sangamithirai KM, Jayapriya J, Hema J, Manoj R (2015) Evaluation of in-vessel co-composting of yard waste and development of kinetic models for co-composting. Int J Recycl Org Waste Agric 4:157-165. doi:10.1007/s40093-015-0095-1

Shaffer B (2010) Curing compost; an antidote for thermal processing. Acres U.S.A. 40. http://www.soilwealth.com.au/imagesDB/ news/Nov2010_ShafferCompost.pdf

Sudharsan Varma V, Kalamdhad AS (2014) Stability and microbial community analysis during rotary drum composting of vegetable waste. Int J Recycl Org Waste Agric 3:52. doi:10.1007/ s40093-014-0052-4

Sundberg C (2005) Improving compost process efficiency by controlling aeration, temperature and $\mathrm{pH}$ (vol. 2005). Swedish University of Agricultural Sciences, Uppsala, Sweden. http:// pub.epsilon.slu.se/950/

Tchobanoglous G, Theisen H, Vigil S (1993) Integrated solid waste management: engineering principles and management issues. McGraw-Hill, New York

Tognetti C, Mazzarino MJ, Laos F (2007) Improving the quality of municipal organic waste compost. Bioresour Technol 98:1067-1076. doi:10.1016/j.biortech.2006.04.025

Tumuhairwe JB, Tenywa JS, Otabbong E, Ledin S (2009) Comparison of four low-technology composting methods for market crop wastes. Waste Manag 29:2274-2281. doi:10.1016/j.was man.2009.03.015

Zahrim A, Leong P, Ayisah S, Janaun J, Chong K, Cooke F, Haywood S (2016) Composting paper and grass clippings with anaerobically treated palm oil mill effluent. Int J Recycl Org Waste Agric 5:221-230

Zhu N (2007) Effect of low initial C/N ratio on aerobic composting of swine manure with rice straw. Bioresour Technol 98:9-13. doi:10.1016/j.biortech.2005.12.003

Zucconi F, Pera A, Forte M, De Bertoldi M (1981) Evaluating toxicity of immature compost. BioCycle 22:54-57. http://agris.fao.org/ agris-search/search.do?recordID=US8248707 